\title{
THE EFFECT OF CORPORATE GOVERNANCE MECHANISM AND ACCOUNTING CONSERVATIONS ON TAX AVOIDANCE
}

\author{
Dianita Trisusanti ${ }^{1}$ \\ Lodovicus Lasdi ${ }^{2}$ \\ Widya Mandala Catholic University Surabaya \\ lodovicus@ukwms.ac.id
}

\section{A R T I C L E I N F O}

Article history:

Received : 1 October 2018

Revised : 25 October 2018

Accepted : 20 November 2018

\section{Key words:}

Tax avoidance, corporate governance, accounting conservatism.

\section{DOI:}

ttps://doi.org/10.33508/rima.v1i2.2596

\begin{abstract}
A B S T R A C T
Law number 17 about State Finances in Article 11 states that the income of the country consists of tax revenue, non-tax revenue, and grants. From year to year the Indonesian government has always increase revenue target of taxation sector. On the side of the taxpayer (company), tax paid to the government will be recognized as an expense, which in turn tax will reduce the amount of net profit of the company. The company believes that tax evasion provide substantial economic benefits and un-expensive sources of financing. The purpose of this study was to examine and analyze whether the corporate government mechanism (institutional ownership concentration, the percentage of independent board, the number of commissioners, the number of audit committee, and quality audits) and accounting conservatism take effect on tax avoidance. This research is a quantitative research with the object of research is manufacturing companies listed in Indonesia Stock Exchange from 2010 to 2013. Data were obtained from the publication of the audited financial statements or annual reports by IDX and book of ICMD. Sampling in this study used purposive random sampling. Data analysis techniques used in this research is regression analysis Ordinary Least Square (OLS). The results showed that the corporate governance mechanism influence on tax avoidance. Three of five proxy mechanism of corporate governance have significant effect on tax avoidance, those three proxies are institutional ownership, number of board of directors, and audit committees, while two other proxy are the percentage of independent board and audit quality which have unsignificant effect on tax avoidance.
\end{abstract}

\section{INTRODUCTION}

Tax avoidance is one of the functions of tax planning. According to Dyreng, Hanlon, and Maydew (2010), tax avoidance is any activity that can reduce the effective tax rates paid by companies. Corporate tax avoidance decisions are made by managers (Desai and Dharmapala, 2006). Corporate tax avoidance opens opportunities for managers to be opportunistic by tax avoidance for shortterm profit purposes, not for long-term benefits expected by shareholders (Minnick and Noga, 2010). Only the pursuit of short- term profits can be dangerous for the survival of a company's business. This is where good corporate governance (Good Corporate Governance) can control the effects of agency problems on tax avoidance (Desai and Dharmapala, 2006). Accounting conservatism that results in profit and asset figures that tend to be lower, and costs and debt figures tend to be higher, can indicate tax avoidance practices. Tax avoidance by companies is usually done through policies taken by the company and not accidentally (Budiman and Setyono, 2012). 
Based on the background described above, the formulation of the problem is as follows. First, do corporate governance mechanisms (concentration of institutional ownership, percentage of independent commissioners, number of boards, number of audit committees, and audit quality) influence tax avoidance? Second, does accounting conservatism affect tax avoidance? The purpose of this research is first to examine and analyze the effect of corporate governance mechanisms (concentration of institutional ownership, percentage of independent commissioners, number of commissioners, number of audit committees, and audit quality) on tax avoidance. Second, to examine and analyze the effect of accounting conservatism on tax avoidance.

\section{LITERATURE REVIEW}

The emergence of the practice of tax avoidance can be explained by agency theory. From year to year, the government tries to increase state revenue through taxation. On the other hand, taxes have an essential role for the survival of the company, the fee paid by the company to the government will be recognized as an expense, so that in the end the tax will reduce the amount of net profit the company receives. The difference in views between the government and company management regarding fees, causing many companies when they have a high tax burden, will tend to encourage management to overcome them in various ways, one of them by manipulating corporate profits (Wulandari, Kumalahadi, and Prasetyo, 2004).

\section{$\underline{\text { Tax Evasion }}$}

Tax avoidance is one function of tax planning. Proper tax planning is tax planning that can distinguish between acts of tax avoidance with tax smuggling (tax evasion). Balter (1983) in Zain (2007: 49) defines tax smuggling as an attempt by taxpayers to reduce or write off tax debt based on the applicable provisions as a violation of taxation laws while tax avoidance means business is carried out by taxpayers. Whether successful or not, reduce or eliminate tax debt that does not violate the provisions of tax legislation.

\section{Corporate Governance}

According to the Forum for Corporate Governance in Indonesia (FCGI, 2001), corporate governance is a set of regulations governing the relationship between the stakeholders. Stakeholders are shareholders, managers (managers) of the company, creditors, government, employees, and other internal and external stakeholders relating to rights and their obligations, or in other words, a system that regulates and controls the company. The corporate governance mechanism is a precise procedure and relationship between the party making decisions and those who manage or supervise the decisions. Several corporate governance mechanisms are often used in research to determine their effects on tax avoidance, including institutional ownership, the structure of the board of commissioners, audit committee, and audit quality (Annisa and Kurniasih, 2012).

\section{Accounting Conservatism}

According to the FASB Statement of Concept No. 2, conservatism is a cautious reaction in the face of uncertainty to ensure that the change and risks inherent in a business situation have been considered. Juanda (2007) states that conservatism is an accounting principle that, if implemented, will result in profit and asset figures tend to below, as well as cost and debt figures tend to be high.

\section{Hypothesis Development}

Companies that have a more substantial shareholding owned by other companies and the government will tend to be watched by institutional investors so that the performance of company management in obtaining the desired profits will get more excellent supervision by investors. This encourages company management to minimize the amount of tax owed to achieve the desired profit so that companies tend to 
avoid charges. Based on these explanations, a hypothesis can be arranged as follows:

H1: The concentration of institutional ownership has a positive effect on tax avoidance.

The board of commissioners is the peak of the company's internal control. The board of commissioners has a significant role in implementing good corporate governance. With the board of commissioners, it is expected that financial reporting can be more reliable and relevant to its operational activities. Financial statements that are not appropriately monitored can be the start of company management to avoid tax. The independent commissioner is the best position to carry out the monitoring function to create good corporate governance (Ujiyantho and Pramuka, 2007). An increasing number of board of commissioners is expected to be able to carry out better-monitoring functions and financial reporting that is more reliable and relevant so that it can suppress the practice of tax avoidance. Based on these explanations, the following hypotheses can be arranged: H2a: Percentage of independent boards of the commission has a negative effect on tax avoidance.

$\mathrm{H} 2 \mathrm{~b}$ : The number of the board of commissioners has a negative effect on tax avoidance.

An audit committee is a committee formed by the board of commissioners to oversee the company's management. The audit committee has the responsibility to assist the board of commissioners in carrying out their duties, especially those relating to company accounting policies, internal controls, and financial reporting systems. The audit committee's functioning effectively enables better control of the company and financial statements and supports good corporate governance (Andriyani, 2008 in
Kurniasih and Sari, 2013). Annisa and Kurniasih (2012) and Dewi and Jati (2014) provide empirical evidence that there is a significant influence of the audit committee on tax avoidance. Based on these explanations, a hypothesis can be arranged as follows:

H3: The number of audit committees has a negative effect on tax avoidance.

Users of financial statements think that audit quality can occur if the auditor can guarantee that there are no material misstatements or fraud in the audited financial statements. Annisa and Kurniasih (2012) stated that the audited financial statements by Big Four KAP auditors are considered to be more qualified because big four auditors are considered more able to limit earnings management practices compared to non-big four auditors. Companies that are not audited by the Big Four KAP can avoid more significant tax than companies that are reviewed by the Big Four KAP. Annisa and Kurniasih's research (2012) shows that there is a substantial effect of audit quality on tax avoidance. Based on these explanations, the following hypotheses can be arranged:

H4: Audit quality has a negative effect on tax avoidance

Accounting conservatism produces profit and asset figures that tend to be lower, and costs and debt figures that tend to be higher can indicate the existence of tax avoidance practices. Companies with a high level of conservatism will produce lower profits so that the tax burden that should be paid is smaller and can indicate tax avoidance. Based on these explanations, the following hypotheses can be arranged:

H5: Accounting conservatism has a positive effect on tax avoidance. 


\section{Model Analysis}

\section{Figure 1: Model Analysis}

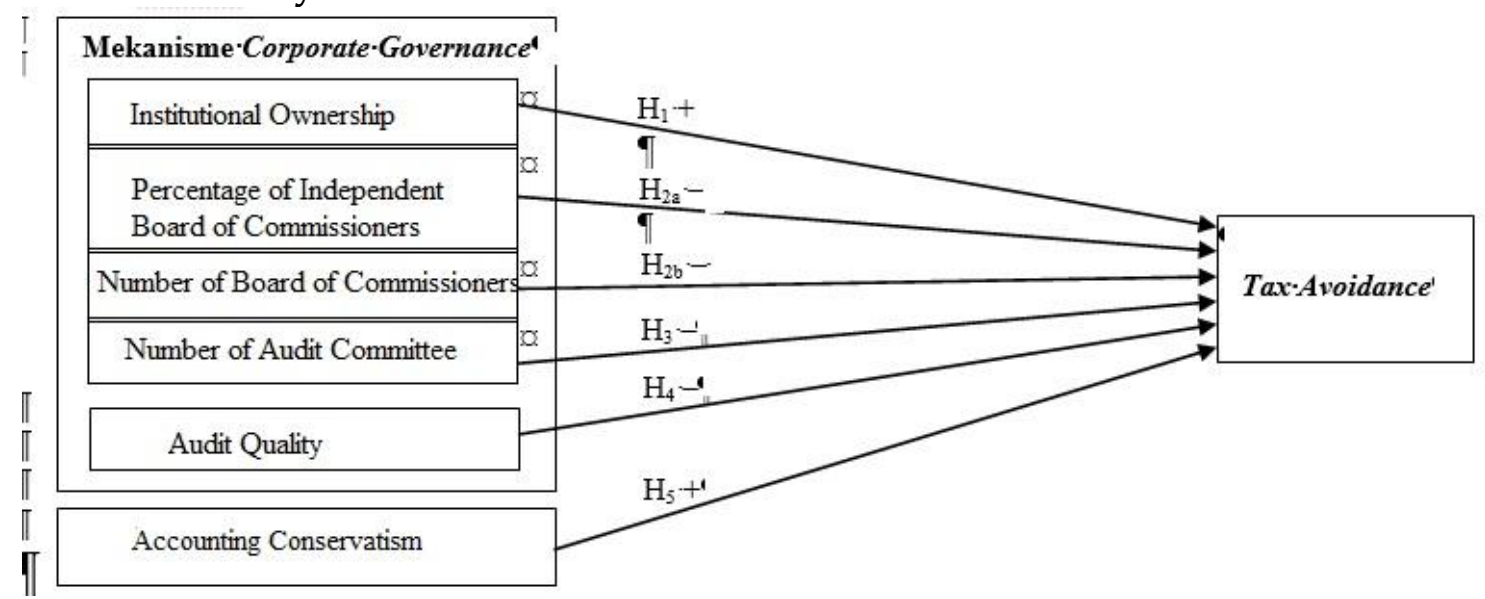

\section{METHODOLOGY}

\section{Research design}

This research is quantitative research with hypothesis testing. Data collection techniques used in this study are data collection techniques in the database because this study uses secondary data obtained from the financial statements of companies listed on the IDX.

Variable Identification, Operational Definitions, and Measurement of Variables

Tax avoidance is defined as an effort to reduce taxes but still comply with tax regulations, such as utilizing permitted exceptions and deductions and delaying taxes that have not been regulated in applicable tax regulations (Heru, 1997 in Budiman and Wijayanti, 2013). The concentration of institutional ownership is the shares of companies or institutions (insurance companies, banks, investment companies, and property of other institutions) (Tarjo, 2008). Independent Commissioners are members of the board of commissioners who are not affiliated with directors, other members of the board of commissioners, and controlling shareholders. They are free from business relationships or other relationships that can affect their ability to act independently or act solely in the interests of the company (National Committee on Governance Policy, 2006). The board of commissioners is the organ of the company that is tasked with supervising in general and specifically following the articles of association and giving advice to directors (Law Number 40 of 2007). Audit Committee is a person or group of at least three independent people in a company that is also selected independently who has capabilities and competencies in accounting and finance. The audit committee is responsible to the board of commissioners (Pohan, 2008 in Annisa and Kurniasih, 2012). De Angelo (1981) defines audit quality as the probability that the auditor will find and report violations in the client's accounting system. Conservatism is defined as a prudent reaction to uncertainty, aimed at protecting the rights and interests of shareholders and debtors which determines a verification of a higher standard for recognizing good news than bad news (Lara, Osma, and Penalva, 2005). 
Table 1: Identification Variable

\begin{tabular}{|c|c|c|c|c|}
\hline Variable & Simbol & Measurement & Reference & Notes \\
\hline Tax avoidance & TA_per & 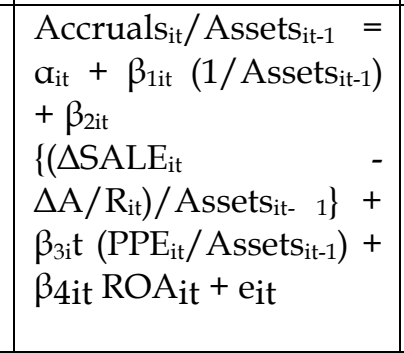 & $\begin{array}{l}\text { Desai } \\
\text { an } \\
\text { Dharmapala } \\
\text { (2006) yang } \\
\text { dimodifikasi } \\
\text { oleh Lim } \\
\text { (2011). } \\
\end{array}$ & $\begin{array}{l}\text { Accruals }=\text { total accruals of } \\
\mathrm{d} \text { company } \mathrm{i} \text { in year } \mathrm{t} \text {, calculated } \\
\text { from ordinary income minus } \\
\text { cash flows from operations. } \\
\text { Assetsit- } 1=\text { total assets of } \\
\text { company } \mathrm{i} \text { in year } \mathrm{t}-1 \text {. }\end{array}$ \\
\hline \multirow[t]{2}{*}{ Tax avoidance } & \multirow[t]{2}{*}{ TA_per } & & & $\begin{array}{l}\Delta \text { SALEit }=\text { change in sales of } \\
\text { company } \mathrm{i} \text { in year } \mathrm{t} \Delta \mathrm{A} / \mathrm{Rit}= \\
\text { change in trade receivables } \\
\text { from company } \mathrm{i} \text { in year } \mathrm{t} \text {. } \\
\text { PPEit = fixed assets (property, } \\
\text { plant, equipment) of company } \mathrm{i} \\
\text { in year } \mathrm{t} \text {. } \\
\text { ROAit = net income of } \\
\text { company } \mathrm{i} \text { in year } \mathrm{t} \text { divided by } \\
\text { total assets. } \\
\text { eit }=\text { residual of company } \mathrm{i} \text { at } \\
\text { year } \mathrm{t} \text {, this residual is then } \\
\text { declared as DA_per }\end{array}$ \\
\hline & & $\begin{array}{l}\text { BTD }_{\text {it }}=b_{1} \text { DA_per } \\
e_{\text {it }}+\end{array}$ & & $\begin{array}{l}\text { BTDi, } t=\text { book-tax difference, or } \\
\text { difference in earnings according } \\
\text { to corporate accounting with } \\
\text { income according to tax } \\
\text { accounting, for company i in } \\
\text { year } t \text { divided by total assets of } \\
\text { the previous year. } \\
\text { DA_peri, } t \text { accrual } \\
\text { discretionary of company i in } \\
\text { year } t \text {. } \\
\text { ei, } t=\text { residual from company } i \\
\text { in year } t \text {, and is used as a } \\
\text { measurement of tax avoidance. } \\
\text { This residual is then stated } \\
\text { as TA_per. }\end{array}$ \\
\hline $\begin{array}{l}\text { Institutional } \\
\text { Ownership }\end{array}$ & INST & 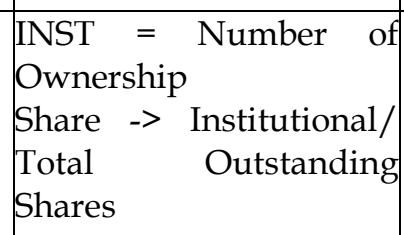 & $\begin{array}{l}\text { Annisa, } \\
\text { Ratnawati, } \\
\text { dan Sofyan } \\
(2012)\end{array}$ & \\
\hline $\begin{array}{l}\text { Percentage of } \\
\text { Independent } \\
\text { Board } \\
\text { Commissioners }\end{array}$ & INDP & $\begin{array}{l}\text { INDP = Number of } \\
\text { Members Independent } \\
\text { Commissioner } \\
\text { Independent/ Total -> } \\
\text { Total ->Members of the } \\
\text { Board of Commissioners }\end{array}$ & $\begin{array}{l}\text { Mayangsari } \\
(2003)\end{array}$ & \\
\hline
\end{tabular}




\begin{tabular}{|c|c|c|c|c|}
\hline $\begin{array}{l}\text { Number of Board } \\
\text { Commissioners }\end{array}$ & DK & $\begin{array}{l}\text { Board of Commissioners } \\
\text { variable } \\
\text { measured by using the } \\
\text { number } \\
\begin{array}{l}\text { commissioners in a } \\
\text { company }\end{array}\end{array}$ & $\begin{array}{l}\text { Siallagan } \\
\text { an } \\
\text { Machfoedz } \\
(2006)\end{array}$ & \\
\hline $\begin{array}{l}\text { Number of Audit } \\
\text { Committee }\end{array}$ & KOMITE & $\begin{array}{l}\text { Audit } \\
\text { variables are measured } \\
\text { by use } \\
\text { the number of audit } \\
\text { committees in a } \\
\text { company }\end{array}$ & \begin{tabular}{l|} 
Pohan \\
08) dalam \\
Annisa dan \\
Kurniasih \\
(2012)
\end{tabular} & \\
\hline Audit Quality & AUDIT & $\begin{array}{l}\text { Audited company } \\
\text { Big Firm will be given a } \\
\text { value of } 1 \text { and if not } \\
\text { audited Big Four Firm } \\
\text { will be given a value of } 0\end{array}$ & $\begin{array}{l}\text { Annisa } \\
\text { an } \\
\text { Kurniasih } \\
(2012)\end{array}$ & Variabel Dummy \\
\hline $\begin{array}{l}\text { Accounting } \\
\text { Conservatism }\end{array}$ & CONACC & $\begin{array}{l}\mathrm{CONACC}_{\mathrm{it}}=-\left(\mathrm{NI}_{\mathrm{it}}-\right. \\
\left.\mathrm{CFO}_{\mathrm{it}}\right)\end{array}$ & $\begin{array}{l}\text { Givoly dan } \\
\text { Hayn } \\
(2000)\end{array}$ & $\begin{array}{l}\text { Nlit = net income before } \\
\text { extraordinary items plus } \\
\text { depreciation and amortization } \\
\text { in company i in year t. } \\
\text { CFOit = cash flow from } \\
\text { operating activities at company } \\
\text { i in year t.. }\end{array}$ \\
\hline
\end{tabular}

\section{Data Types and Data Sources}

The type of data used in this study is quantitative data. Quantitative data in this study is based on audited financial statements or annual reports published by the IDX and ICMD books. The data source used in this study is secondary data. This study's data source is the audited financial statements or annual reports of manufacturing companies from 2010 to 2013.

\section{Population, Samples, and Sampling Techniques}

The population in this study includes manufacturing companies listed on the Stock Exchange from 2010 to the end of 2013. Sampling in this study was conducted by purposive random sampling, which is part of the non-probability sampling method, namely the selection of non-random samples with the following criteria:

1. Manufacturing companies listed successively on the IDX during the period 2009-2013.
2. Companies whose audited financial statements or annual reports can be accessed during the period 2010-2013.

3. The company publishes audited financial statements or annual reports which are presented in rupiah during 2010-2013.

4. Audited financial statements or annual reports have the data needed for four years of research (2010-2013).

\section{Data analysis technique}

Hypotheses $\mathrm{H} 1$ through $\mathrm{H} 5$ will be tested using Ordinary Least Square (OLS) regression analysis with the following regression equation:

TA_per ${ }_{t}=\alpha+\beta$ IINSTt- $1+\beta 2$ INDPt- $1+$ $\beta 3 \mathrm{DKt}-1+\beta 4$ KOMITEt-1 $+\beta 5$ AUDITt $-1+$ $\beta 6 \mathrm{CONACCt}-1+\mathrm{e}$

Where :

TA_per $=$ tax avoidance in year $\mathrm{t}$ INST $=$ institutional ownership in year $\mathrm{t}-1$

INDP $=$ percentage of independent commissioners in year $t-1$ DK $=$ number of 
boards of commissioners in year $\mathrm{t}-1$

COMMITTEE $=$ number of audit committees in year $\mathrm{t}-1$ AUDIT = audit quality in year $\mathrm{t}-1$

CONACC $=$ accounting conservatism in year

$\mathrm{t}-1 \mathrm{a}=$ constant

$\beta=$ regression coefficient

$\mathrm{e}=$ error term

The level of significance $(\alpha)$ used was 0.05 . If the $p$-value is higher than the level of significance, the independent variable has no significant effect on the dependent variable. Conversely, if the $p$-value is lower than the level of significance, the independent variable has a significant impact on the dependent variable.

\section{RESULT AND DISCUSSION}

The institutional ownership regression coefficient of 0.028 shows that institutional ownership has a positive effect on tax avoidance; if institutional ownership is higher, it will increase tax avoidance. Therefore, H1 proposed in this study is "The concentration of institutional ownership has a positive effect on tax avoidance" is accepted because, based on statistical testing of the regression equation that the concentration of institutional ownership has a significant positive effect on tax avoidance. This positive effect means that the higher the level of institutional ownership, the greater the tax avoidance that is carried out. Increasing the concentration of institutional ownership will encourage company management to achieve the desired profits so that companies tend to avoid tax.

$\mathrm{H} 2 \mathrm{a}$ proposed in this study is "The percentage of independent commissioners has a negative effect on tax avoidance." H2a was rejected because, based on the regression equation's statistical testing, the percentage of the board of independent directors had no significant effect on tax avoidance. The results of this study confirm Annisa and Kurniasih's (2012) research that the percentage of independent commissioners does not have a significant and negative effect on tax avoidance. Like the results of this study, the rate of independent commissioners does not significantly influence tax avoidance but has a positive impact on tax avoidance. This is different from the results of Annisa and Kurniasih's (2012) research. This shows that an independent board of commissioners is not useful in implementing good corporate governance, so it does not prevent tax avoidance. A member of the company's independent board of commissioners is possible only to fulfill the stipulated provisions.

$\mathrm{H} 2 \mathrm{~b}$ proposed in this study is "The number of boards of commissioners has a negative effect on tax avoidance." $\mathrm{H} 2 \mathrm{~b}$ is rejected because, based on the regression equation's statistical testing, the number of boards of commissioners has a significant positive effect on tax avoidance. This positive effect indicates that the more the number of boards of commissioners, the higher the company's tax avoidance. Annisa and Kurniasih (2012) stated that the effectiveness of control over tax avoidance depends on the values, norms, and trust received in a company and the role of the board of commissioners in controlling management activities, so it can be said that the board of commissioners supports the management of the company to minimize the amount of tax burden owed by the company through tax avoidance activities.

H3 proposed in this study is "The number of audit committees has a negative effect on tax avoidance." H3 is accepted because, based on the regression equation's statistical testing, the number of audit committees has a significant negative effect on tax avoidance. This study confirms Annisa and Kurniasih's (2012) research that the number of audit committees has a significant positive impact on tax avoidance. Like the results of this study, the number of audit committees has a substantial effect on tax avoidance but has a contrary nature towards tax avoidance. This negative effect means that the more the number of audit committees, the tax avoidance will be reduced, so it can be said that the function of the audit committee has run effectively and supports good corporate governance. 
H4 proposed in this study is "Audit quality has a negative effect on tax avoidance." H4 is rejected because it is based on the regression equation's statistical testing that audit quality does not significantly influence tax avoidance. These results confirm the research of Jaya et al. (2013). In the study of Annisa and Kurniasih (2012), audit quality has a significant positive effect on tax avoidance. In the review of Jaya et al. (2013), audit quality does not affect tax avoidance. According to Jaya et al. (2013), it is tax ethics that influence taxpayers to avoid taxation and do not see the results of audits of corporate financial statements as a consideration in tax avoidance. The higher the moral ethics, the lower the taxpayer's intention to avoid tax.

H5 proposed in this study is "Accounting conservatism has a positive effect on tax avoidance." H5 is rejected because, based on statistical testing of the regression equation that accounting conservatism has no significant effect on tax avoidance. The existence of taxation laws regarding the use of conservatism limits companies to carry out tax avoidance through the principle of conservatism. One of them is the Article 9 of the Income Tax Act concerning expenses that cannot be deducted in the fiscal income statement, thus causing a budgetary reconciliation regarding any formation or accumulation of reserve funds (uncollectible receivables, inventory losses, etc.) by the company. The allowance for damages will be corrected positively fiscal, which will cause the company's profits to increase, so that management cannot carry out tax avoidance through the principles of conservatism.

\section{CONCLUSIONS, LIMITATIONS, AND SUGGESTIONS}

Conclusion

Based on the results of the analysis and discussion discussed earlier, it can be concluded that first, the corporate governance mechanism influences tax avoidance. Second, accounting conservatism does not affect the level of tax avoidance in the company.

\section{Limitation}

The first limitation is the generalization of the results of this study is in companies engaged in the manufacturing sector. The second limitation is based on the results of the test of the coefficient of determination can be interpreted the ability of institutional ownership variables, the percentage of independent commissioners, the number of commissioners, audit committees, audit quality and accounting conservatism in explaining the variable tax avoidance is limited, only able to explain variations of $5.9 \%$. In contrast, the remaining $94.1 \%$ is influenced by other factors. The third limitation is that the period in this study is only four years, namely the period 2010-2013. Extensive research on accounting conservatism is carried out observations of the five-year research period. This research is limited by the year the Income Tax Law No. 36 of 2008, which entered into force in 2010 , so the period of this study began from 2010 to 2013.

\section{Suggestion}

The first suggestion is that further research can further expand the sample, so it is not limited to manufacturing companies. The second suggestion is to add another independent variable that can explain tax avoidance appropriately or replace other proxies to get the right independent variable, such as company risk, company size, fiscal loss compensation, etc. The third suggestion is to expand the research period, which can be done at least five years from the research period since the enactment of the Income Tax Law No. 36 of 2008, which came into force in 2010.

\section{REFERENCES}

Ahmed, Anwer S., dan S. Duellman, 2007, Accounting Conservatism And Board Of Director Charateristics: An Empirical Analysis, Social Science Research Network. 
Annisa, Nuralifmida Ayu dan Lulus Kurniasih, 2012, Pengaruh Corporate Governance Terhadap Tax Avoidance, Jurnal Akuntansi \& Auditing, Volume 8 Nomor 2: 123 - 136.

Armstrong, Christopher S., J. L. Blouin, A. D. Jagolinzer, dan D. F. Larcker, 2014, Corporate Governance, Incentives, and Tax Avoidance, Social Science Research Network.

Badertscher, Brad A., J. J. Burks, dan P. D. Easton, 2012, A Convenient Scapegoat: Fair Value Accounting by Commercial Banks during the Financial Crisis, The Accounting Review, 87 (1): 59-90.

Basu, Sudipta, 1997, The Conservatism Principle and The Asymmetric Timeliness of Earnings, Journal of Accounting and Economic, Vol. 24, No.1: 3-37.

Boediono, Gideon S. B., 2005, Kualitas Laba: Studi Pengaruh Mekanisme Corporate Governance dan Dampak Manajemen Laba dengan Menggunakan Analisis Jalur, Simposium Nasional Akuntansi VIII, Solo.

Budiman, Judi dan Setiyono, 2012, Pengaruh Karakter Eksekutif terhadap Penghindaran Pajak (Tax Avoidance).

Electronic Thesis $\mathcal{E}$ Dissertations (ETD) Univeritas Gajah Mada.

Budiman, Judi dan P. Wijayanti, 2013, Analisis Perbedaan Penghindaran Pajak (Tax Avoidance) pada Perusahaan yang Dikenai Pajak Penghasilan Final dan Perusahaan yang Dikenai Pajak Penghasilan Tidak Final, Prosiding Simposium Nasional Perpajakan 4.
Christiawan, Yulius Jogi, 2002, Kompetensi dan Independensi Akuntan Publik: Refleksi Hasil Penelitian Empiris,

Jurnal Akuntansi \& Keuangan, Vol. 4, No. 2, Nopember 2002: 79 - 92.

DeAngelo, Linda Elizabeth, 1981, Audit Size and Audit Quality, Journal of Accounting $\mathcal{E}$ Economics 3.

Deis, Donald R., dan G. A. Giroux, 1992, Determinants of Audit Quality in The Public Sector, The Accounting Review, Juli, p. 462-479.

Desai, M.A., Dharmapala, D., 2006. Corporate Tax Avoidance and High Powered Incentives. Journal of Financial Economics 79, 145-179.

Dewi, Ni Nyoman Kristiana, dan I Ketut Jati, 2014, Pengaruh Karakter Eksekutif, Karakteristik Perusahaan, dan Dimensi Tata Kelola Perusahaan yang Baik pada Tax Avoidance di Bursa Efek Indonesia, E-Jurnal Akuntansi Universitas Udayana.

Dyahayu, Artika Deviyanti, dan S. N. Rahardjo, 2012, Analisis Faktor-faktor yang Mempengaruhi Penerapan Konservatisme dalam Akuntansi, Semarang, Universitas Diponegoro.

Dyreng, Scott D, M. Hanlon, dan E. L. Maydew, 2010, The Effects of Executives on Corporate Tax Avoidance, The Accounting Review, Vol. 85, No. 4: 1163-1189.

FASB, 1980, Statement of Financial Accounting Concepts No. 2, Qualitative Characteristics of Accounting Information.

FCGI, 2001, Corporate Governance: Tata Kelola Perusahaan, Edisi Pertama, Jakarta. 
Ghozali, Imam, 2011, Aplikasi Analisis Multivariate dengan Program IBM SPSS 19, Edisi Kelima, Semarang: Badan Penerbit Universitas Diponegoro.

Gunadi, 2009, Akuntansi Pajak: Sesuai dengan Undang-Undang Pajak Baru Edisi Revisi 2009, Grasindo, Jakarta. Hastuti, Rini, dan D. A. Retnaningsih, 2010, Kepatuhan Wajib Pajak Ditinjau dari Faktor Internal dan Eksternal,

Semarang, Laporan Penelitian Universitas Katolik Soegijapranata.

Hogan, Chris E., 1997, Cost and Benefits of Audit Quality in The IPO Market: A Self Selection Analysis. The Accounting Review, Januari. p. 67-86.

Iskander, Magdi R. dan Nadereh Chamlou, 2000, Corporate Governance: A Framework for Implementation. The International Bank for Reconstruction and Development. The World Bank.

Jaya, Tresno E., M. Y. Arafat, dan D. Kartika, 2013, Corporate Governance, Konservatisme Akuntansi, dan Tax Avoidance, Prosiding Simposium Nasional Perpajakan 4.

Jensen, M. C., dan Meckling, W. H., 1976, Theory of the Firm: Managerial Behavior, Agency Costs and Ownership Structure, Journal of Financial Economics, Oktober, 1976, V. 3, No. 4, pp. 305-360.

Juanda, Ahmad, 2007, Pengaruh Risiko Litigasi dan Tipe Strategi terhadap Hubungan antara Konflik Kepentingan dan Konservatisma Akuntansi, Simposium Nasional Akuntansi X, Makassar.

Khurana, I. K., dan W. J. Moser, 2009, Shareholder Investment Horizons and Tax Aggressiveness, Social Science
Research Network.

Kiryanto dan E. Supriyanto, 2006, Pengaruh Moderasi Size terhadap Hubungan Laba Konservatisma dengan Neraca Konservatisma, Simposium Nasional Akuntansi 9, Padang.

Komite Nasional Kebijakan Governance (KNKG), 2006, Pedoman Umum Good Corporate Governance Indonesia, Jakarta.

Kurniasih, Tommy dan M. M. R. Sari, 2013, Pengaruh Return On Assets, Leverage, Corporate Governance, Ukuran Perusahaan Dan Kompensasi Rugi Fiskal Pada Tax Avoidance, Buletin Studi Ekonomi, Volume 18, No. 1, Februari 2013.

Lara, M. G. L., B. G. Osma, dan F. Penalva, 2005, Board Of Directors' Characteristics and Conditional Accounting Conservatism: Spanish Evidence, Social Science Research Network.

Lim, Youngdeok, 2011, Tax Avoidance, Cost of Debt and Shareholder Activism: Evidence from Korea, Journal of Banking $\mathcal{E}$ Finance 35.

Mayangsari, S., Analisis Pengaruh Independensi, Kualitas Audit, serta Mekanisme Corporate Governance terhadap Integritas Laporan Keuangan. Simposium Nasional Akuntansi VI, Surabaya.

Minnick, Kristina dan T. Noga, 2010, Do Corporate Governance Characteristics Influence Tax Management?, Journal of Corporate Finance 16.

Muntoro, Ronny Kusuma, 2007, Membangun Dewan Komisaris yang Efektif, Majalah Usahawan Indonesia 
No.11 Tahun XXXVI, Lembaga Manajemen FEUI, Jakarta.

Santoso, S. , 2010, Statistik Parametrik, Jakarta: Elex Media Komputindo.

Scott, William R., 2000, Financial Accounting Theory, Second Edition, Canada: Prentice-Hall Canada Inc.

Siallagan, Hamonangan, dan Mas'Ud Machfoedz, 2006, Mekanisme Corporate Governance, Kualitas Laba dan Nilai Perusahaan, Simposium Nasional Akuntansi 9, Padang.

Suandy, Erly, 2008, Perencanaan Pajak, Edisi Keempat, Jakarta: Salemba empat. Suandy, Erly, 2011, Hukum Pajak, Edisi Kelima, Jakarta: Salemba empat.

Suwardjono, 2013, Teori Akuntansi: Perekayasaan Pelaporan Keuangan, Edisi Ketiga, Cetakan Keenam, Yogyakarta, BPFE-Yogyakarta.

Tarjo, 2008, Pengaruh Konsentrasi Kepemilikan Institusional dan Leverage terhadap Manajemen Laba, Nilai Pemegang Saham serta Cost of Equity Capital, Simposium Nasional Akuntansi XI.

Timothy, Yeung Chi Kwan, 2010, Effects of Corporate Governance on Tax Aggressiveness, Hong Kong Baptist University.

Undang-Undang Republik Indonesia Nomor 17 Tahun 2003 Tentang Keuangan Negara. Undang-Undang Republik Indonesia Nomor 40 Tahun 2007 Tentang Perseroan Terbatas. Watts, R. L. dan J. L. Zimmerman, 1986, Positive Accounting Theory. New York, Prentice Hall.

Watts, R. L., 2003, Conservatism in Accounting Part I: Explanations and
Implications, Accounting Horizons 17, 207- 221.

Wulandari, D., Kumalahadi, dan J. E. Prasetyo, 2004, Indikasi Manajemen Laba Menjelang Undang-Undang Perpajakan 2000 pada Perusahaan Manufaktur yang Terdaftar di Bursa Efek Jakarta, Simposium Nasional Akuntansi VII, Bali.

Zain, Mohammad, 2007, Manajemen Perpajakan, Edisi Kedua, Jakarta: Salemba Empat. 